Nowoczesne Systemy Zarządzania

Zeszyt 15 (2020), nr 4 (październik-grudzień)

ISSN 1896-9380, s. 27-38

DOI: $10.37055 / \mathrm{nsz} / 133650$

Modern Management Systems

Volume 15 (2020), No. 4 (October-December)

ISSN 1896-9380, pp. 27-38

DOI: $10.37055 / \mathrm{nsz} / 133650$
Instytut Organizacji i Zarządzania Wydział Bezpieczeństwa, Logistyki i Zarządzania

Wojskowa Akademia Techniczna

w Warszawie

Institute of Organization and Management Faculty of Security, Logistics and Management Military University of Technology

\title{
Shifting from Face to Face to Online Teaching Due to COVID-19 Pandemic - Personal Assessment of American and Polish Higher Education Teachers
}

\section{Przejście od tradycyjnego nauczania do nauczania online w związku z pandemią COVID-19 - ocena osobista amerykańskich i polskich nauczycieli reprezentujących uczenie wyższe}

\author{
Celina Sołek-Borowska ${ }^{1}$ \\ Military University of Technology, \\ Faculty of Security, Logistics and Management \\ celina.solek@wat.edu.pl, ORCID: 0000-0002-2411-9677 \\ Brian Buckles $^{2}$ \\ National Defence University, USA \\ Dwight D. Eisenhower School for National Security and Resource Strategy \\ ORCID: 0000-0003-3342-0952
}

\begin{abstract}
As a result of the COVID-19 pandemic, many faculty members were required to abruptly shift from face-to-face to online teaching. Within this, some instructors managed well, while others struggled. This COVID-19 induced shift to online teaching constitutes a clear achievement situation is that for many faculty members, it marked the first time that it was mandatory for all courses to be exclusively taught online what proved to be challenging for teachers. Therefore the objective of the paper is to present first-hand experience of academic teachers in Poland and USA representing Military University of Technology and National Defence University in USA.

Given the sudden nature of transitioning from an in-residence program to an online program, the Eisenhower School in USA and Faculty of Security, Logistics and Management in Poland encountered many issues identified in the literature, like understanding student learning styles and culture; applying best pedagogical
\end{abstract}

1 The views expressed in this paper are those of the author and do not reflect the official policy or position of the Military University of Technology, Faculty of Security, Logistics and Management.

2 The views expressed in this paper are those of the author and do not reflect the official policy or position of the Eisenhower School, the National Defense University, or the Department of Defense. 
approaches; managing technology and technological issues; receiving sufficient technical training; and preparation and execution time management challenges (Islam, Beer, and Slack 2015).

The authors postulate that online teaching should be regarded as complimentary to traditional teaching, as nothing will replace face to face contact.

Keywords: online teaching, COVID-19 pandemic, e-learning

Abstrakt. W wyniku pandemii COVID-19 wielu członków wydziału musiało nagle przejść z nauczania bezpośredniego na nauczanie online. Niektórzy instruktorzy radzili sobie dobrze, podczas gdy inni mieli trudności. Wywołane przez COVID-19 przejście na nauczanie online przelożyło się na osiągnięcia nauczania, ponieważ dla wielu członków wydziału po raz pierwszy prowadzenie kursów wyłącznie przez Internet było obowiązkowe, co okazało się wyzwaniem dla nauczycieli. Dlatego celem artykułu jest przedstawienie doświadczeń z pierwszej ręki polskich i amerykańskich nauczycieli akademickich reprezentujących Wojskową Akademię Techniczną i Akademię Obrony Narodowej w USA. Biorąc pod uwagę nagłe przejście z programu stacjonarnego do programu online, Eisenhower School w Stanach Zjednoczonych oraz Wydział Bezpieczeństwa, Logistyki i Zarządzania w Polsce napotkały wiele problemów zidentyfikowanych w literaturze, takich jak: zrozumienie stylów uczenia się uczniów; stosowanie najlepszych podejść pedagogicznych; zarządzanie technologią i zagadnieniami technologicznymi; otrzymanie wystarczającego szkolenia technicznego; a także wyzwania związane z przygotowaniem i zarządzaniem czasem podczas zajęć online (Islam, Beer, Slack 2015). Autorzy postulują, że nauczanie online należy traktować jako uzupełnienie nauczania tradycyjnego, gdyż nic nie zastąpi bezpośredniego kontaktu nauczyciela i studenta.

Słowa kluczowe: nauczanie online, pandemia COVID-19, e-learning

\section{Introduction}

As a result of the COVID-19 pandemic, many faculty members were required to abruptly shift from face-to-face to online teaching. Consequently, some struggled and experienced hurdles and high stress levels, while others perceived this sudden shift to be a positive opportunity, managed to cope well, and facilitated positive learning activities for their students (Bhat et al., 2020; Ortiz, 2020). This COVID-19 induced shift to online teaching constitutes a clear achievement situation in that for many faculty members, it marked the first time that it was mandatory for all courses to be exclusively taught online, thereby entailing a relevant learning and qualification situation where it was simultaneously important to perform well and successfully support student.

By the decision of the Ministry of Education in Poland from March 11, 2020, it has been announced that all teaching activities are suspended as from March 12 until March 25, 2020 (https://www.gov.pl/web/edukacja/zawieszenie-zajec-w-szkolach). The decision has been upheld so the summer semester of 2019/2020 and winter semester 2020/21 have been continued in an online mode. Similarly, the National Defense University suspended face-to-face education beginning March 16, 2020 through the end of academic year 2020. Academic year 2021 began August 4, 2020 in an online format, and continues online through March 2021.

Following the instructions of the central government, all the state governments in Poland closed all kinds of schools, universities, businesses, traffic, etc. to control the spread of the pandemic. Universities are the key points of social gathering and 
in this scenario of a pandemic, students and faculty members were forced to live within their houses. In the United States, federal, state, and local governments implemented similar measures to minimize the spread of the COVID virus. While individual faculty members could come to the National Defense University to work, most opted not to and conducted to teach and work from home.

As such, COVID-19 can be seen as a natural paradigm that accentuates interindividual differences in the achievement context of how faculty experience and handle online teaching and learning. While much is known about digital technologies in educational contexts, investigations into personal prerequisites of faculty are especially helpful to better understand differences in the academic practice of online teaching and learning (see Hofer, Nistor, Scheibenzuber, Martin et al., 2020). Specifically, investigating faculty attitudes towards the shift to online teaching as well as their motivational underpinnings can meaningfully illuminate interindividual differences regarding the implementation of online technologies in higher education teaching and how this can be better supported. Therefore, the objective of the paper is to present first-hand experience of academic teachers in Poland and USA representing the Military University of Technology and National Defence University in USA.

The research questions are as follows:

RQ1: How Covid-19 pandemic influenced the higher education sector?

RQ2: What is the assessment of online teaching from the perspective of a teacher in USA and Poland?

The structure of the paper is as follows: the first section deals with literature review on e-learning, the second section addresses the legal steps that have been undertaken due to COVID-19 pandemic in the education sector along with the methodology, and the final section presents personal insights from the USA and Polish perspective. It concludes with summary and avenue for further research.

\section{Literature review}

\subsection{Beginning of e-learning in higher education}

E-learning has been introduced as a fundamental part of the student learning experience in higher education in may developed countries all over the world. It is no longer core business only for those universities with a mission for distance education, its affordances are being systematically integrated into the student learning experience by predominately campus-based universities. Evidence of this widespread uptake can be noticed in reputable research journals which undertake the research of e-learning and on the websites of leading higher education institutions. Examples of these institutions include mainly universities from UK, USA, and Australia. 
To assess online teaching, one must consider challenges like the use of software, hardware, Internet connectivity, etc. For example, Sarrayrih and Ilyas (2013) discussed the various challenges of online examinations from an authentication and security perspective. Ozden et al. (2004) investigated students' perspective of online assessment and found immediate feedback, randomized question order, item analysis of question and immediate scoring as the prominent features of online examination. Baleni (2015) discussed the various benefits of online formative assessment like improvement in students' commitment, faster feedback, etc. Khan and Khan (2019) explored students' perspective of online assessment and found that technological incompetence of students and faculty alongside distrust in technology infrastructure are some points of stress. Stowell and Bennett (2010) found the opposite effect of anxiety on students between appearing in classroom examination and online examination.

\subsection{Developments of e-learning}

Keeping the growing demand of online education, a number of online courses have taken place with time. Dave Cormier coined the term "MOOC" for "Massive open online course" in 2008. MOOCs provide an affordable and flexible way to learn new skills, advance ones career and deliver quality educational experiences at scale (www.mooc.org). MOOCs have received tremendous response from students worldwide (Rai, 2019). MOOCs provide students an alternative way of getting subject knowledge with certification though online mode. O'Connor (2014) made an analysis of the initial stages of various approaches to MOOCs.

"Open" refers to the fact that the work is out in the open, accessible to everyone. The work presented by the course facilitators as well as the work done by participants is all available for everyone to learn from and reflect on. Rather than completing assignments, students are expected to contribute and engage in the community (MOOC Courses: Massive Open Online Courses [2021 Guide] (mydegreeguide.com)). Due to the availability of a number of course, modules online, MOOCS have shown a digital revolution in higher education (Kaplan, Haenlein, 2016). A number of universities are offering MOOCS as a supplementary course to the students. Ahmad et al. (2017) in their work provided the statistics of a university where MOOCs are offered as supplementary to higher education. Online education has a great impact on higher education. Students have the facility to choose the best available course for them outside the classroom. Aithal and Aithal (2016) discussed the impact of online education in higher education system. McConnell (2018) presented views of faculty members teaching in Chinese universities about e-learning. Demir (2018) discussed the benefits and challenges of Facebook as an online assessment tool. An effective online learning depends on too many factors like presentation skill, content delivery, use of technology, etc. Crawford-Ferre and Wiest (2012) summarized some effective practices in online instructional methods. 
Though, the online education is growing day by day, it has its own challenges. Swan (2017) examined barriers faced by students who struggle to learn when isolated in an online environment. Islam, Beer, and Slack (2015) identify five categories of challenges associated with teaching online: understanding student learning styles and culture; applying best pedagogical approaches; managing technology and technological issues; receiving sufficient technical training; and preparation and execution time management challenges. Finally, O’Neill and Sai (2014) examined reasons that students prioritize to face-to-face lectures compared to online lectures and found that some felt they would learn more when hearing a lecture directly in person and that they would be more engaged with the material.

\section{COVID-19 and higher education}

As per UNESCO, on April 1,2020, education institutions in 185 countries were closed, thus the emergence of COVID-19 affected education globally. Association of Universities (IAU Report, 2020) provided a detailed report of the impact of COVID-19 on higher education across the globe. In this time of crisis UNESCO (Issue Note 2.4 April 2020a) provided a detailed planning to deal with the effects of COVID-19 in education systems. UNESCO (Issue Note 4.3 May 2020b) discussed the various strategies adopted by countries to cope with the current situation. UNESCO has already recommended some parameters for e-learning (Chatelier, Voicu, 2018). In the wake of COVID-19 pandemic, Polish Ministry of Education has made available the lists of various platforms for digital learning in Poland (Nauka zdalna podczas zawieszenia zajęć w szkołach - rekomendacje dla nauczycieli i dyrektorów - Ministerstwo Edukacji Narodowej, www.gov.pl, 15.09.2020).

Regarding faculty experiences, COVID-19 has elicited considerable feelings of stress and strain while adapting to online teaching and learning (Besser et al., 2020). Whether these experiences impact faculty well-being, depends on their construal of this distress (see Sabagh et al., 2018, for an overview). Here, attitudes can be regarded as resources or determinants of individuals' primary and secondary appraisals of stressors, and as such, matter for the manifestation of stress (Folkman et al., 1986; see Daumiller, Dresel, 2020). The latter is commonly described with the concept of "burnout" (Freudenberger, 1974) that is understood as an erosion of occupational engagement (Maslach, Leiter, 2008) and constitutes a continuum running from a positive pole (engagement) to a negative pole (burnout) of handling work situations. It includes emotional exhaustion (feeling depleted and no longer interested in one's we expect faculty attitudes towards this shift to also matter for teaching practice, and consequently, students' evaluations of teaching quality in terms of learning.

By perceiving the online teaching situation as threatening, faculty members can be presumed to hold back and not fully exploit its potential, for example, by 
limiting themselves to teaching in the form of safer (more controllable) and less resource-intensive passive learning activities instead of more constructive and interactive learning activities that could support better learning (e.g. Chi, Wylie, 2014; Wekerle et al., 2020). In particular, faculty members might set out to do more asynchronous instead of synchronous teaching, which is frequently considered less effective due to the reduced interaction level between faculty members and students (Offir et al., 2008).

\subsection{Methodology}

Nowadays, qualitative research is a major branch of inquiry in the social sciences, encompassing a wide range of phenomena. Qualitative studies share a naturalistic and situated concern as the basis of their inquiry: they seek to study phenomena through a person's perspective, paying attention to the context where they emerge (Denzin, Lincoln, 2005). Considering this aim, experience and meaning appear as crucial concepts for reaching a deeper understanding of a participant's perspective, thus improving the qualitative comprehension of the social and psychological phenomena studied.

Taken as a whole, qualitative research ought to focus on describing participants' perspectives or views. Therefore, a qualitatively-oriented methodological device should, first and foremost, make the apprehension of those perspectives easier. These views should be the 'compass' of any qualitative research; since they are the most solid basis for scholars to ground conclusions about how people experienced the phenomena studied (Denzin, Lincoln, 2005). As described above, participants' perspectives are commonly thematized in terms of experiences and their meanings but leaving aside the discussion of what exactly these terms stand for.

In the following study the authors undertook a qualitative type of study basing on their first hand on experiences concerning teaching on-line in their respective Universities.

\subsection{Teaching online in the Military University of Technology}

The Military University of Technology (MUT), established by the Act of 1951, is a public academic university supervised by the Minister of National Defense. As an open technical university, it serves the Armed Forces, science, the economy, and society. It educates cadets and students, and develops research and teaching staff. It conducts research and development work in the areas of exact technical and social sciences, in particular the field of military and security technology. MUT cooperates with academic universities in Poland and abroad.

Military University of Technology (MUT) prepares future engineering staff, transfers knowledge, shapes skills and improves competences at the highest level, teaching students patriotism and responsibility for the homeland. 
The Academy educates students in military and civil studies. Graduates of military studies receive a master's degree in engineering and are appointed to the first officer rank - second lieutenant. Civil studies are generally available studies, with no obligations to the Ministry of National Defense. Higher education allows you to obtain the professional title of engineer or bachelor, master engineer or master. The teaching process at MUT is carried out by eight basic organizational units: Safety, Logistics and Management Department; Faculty of Cybernetics; Faculty of Electronics; Faculty of Civil Engineering and Geodesy; Faculty of Mechanical Engineering; Faculty of Mechatronics, Weapons and Aviation; Faculty of New Technologies and Chemistry; Institute of Optoelectronics.

In Poland, online teaching is not very popular. Considering Military University of Technology all teaching prior to pandemia was taking place in the traditional way. Most of the teachers were not trained either to teach and conduct classes online, either students were not trained at all.

The first two weeks were regarded as a transition period where it was advised to be in contact with students via email or start using Microsoft teams platform. Many academic teachers started to use Microsoft Teams as a dedicated platform for online teaching. The stress was related to fact that most of the teachers did not have any experience in dealing with such platform and prior preparation. The challenge became how to engage students and to keep them motivated. It is not obligatory for students to attend lectures, but it was interesting to see that during pandemia the participation in classes was very high. Features like: private channels, calendar, tasks, general and private chats proved to be helpful in enriching students experience. It is also worth to mention that a lot of students lost their part time job, a ban to gather with others made them as well that attending lectures might be a good option.

The other challenge was that whilst generally having six or eight classes in traditional way worked very well it was noticeable that teaching online for both parties for six or eight hours was tiring. Many academic institutions started to offer free of charge courses online - that were preparing teachers for that mode of delivery. Microsoft offered short introductory videos on their web page. Military University of Technology advices teachers and students to use dedicated platform: e-learning. Considering the impact of pandemic every single course has been run online. Older professors were given help in terms of acquaintance with the Microsoft Teams platform. Speaking from the author own experience few first classes were stressful in order to make sure that students are not bored, interact with the others and to make sure that learning objectives are met. Summing up the summer semester 2019/2020 it can be concluded that it was success.

As the academic year progressed, faculty became more proficient with the technology. With that said, there is a desire by faculty to return to a face-to-face environment, thus some faculty are reluctant to dedicate significant time to training because of opportunity costs. Addressing the future use of online teaching capabilities even during a face-to-face curriculum will need to include dedicated faculty and student training. 


\subsection{Teaching online in the National Defense University}

The Eisenhower School, National Defense University is located in Washington D.C., and has a mission to educate joint warfighters and other national security leaders for strategic leadership and success in developing national security strategy and in evaluating, marshaling, and managing resources in order to execute that strategy. Students are a combination of U.S. military officers, International military officers, Department of Defense civilian employees, and U.S. government employees from other agencies such as the Department of State, Department of Commerce, and the Department of Homeland Security. The students all have extensive work experience ranging from 15 to 25 years. As such, the school employs androgogical teaching methods for adult learners.

Given the sudden nature of transitioning from an in-residence program to an on-line program, the Eisenhower School encountered many of the same issues identified in the literature and as experienced at the Military University of Technology. Using Islam, Beer, and Slack's (2015) themes, this section will illustrate that their lessons remain relevant in 2021. Because the online transition occurred toward the end of academic year (AY) 2020 and continued into the next academic year (AY2021), the school experienced two periods of challenges.

Islam, Beer, and Slack's first challenge category, learning style and cultural challenge (p. 103-104), was not an issue completing AY2020 as the faculty and students already knew each other from nearly eight months of face-to-face contact. However, beginning the next academic year in a virtual environment highlighted the challenges of gaining insight on student learning styles. This author's personal experience with classroom sizes of 15-18 students, indicates taking two to three weeks longer to gain insights on each student's preferred learning style from a face-to-face setting. To fully understand the additional challenges of culture impacting international student learning requires dedicated individual counseling sessions outside of normal class time. Given the Eisenhower School's emphasis on Socratic teaching style, matching it with various student learning styles in an on-line environment is indeed challenging and time consuming; again, consistent with Islam, Beer, and Slack's discussion of Banning's findings (p. 103).

The second challenge category identified by Islam, Beer, and Slack (2015) relates to pedagogical differences between online education and face-to-face learning. Their review of the literature indicates that face-to-face content does not always translate well in an online environment, and as such, online content, "... should be appropriately designed for distance learning...” (p. 105). This challenge was most evident when the Eisenhower School made the sudden transition to online teaching in March 2020. Faculty simply did not have the time or ability to modify academic content to make it "online friendly." However, over the summer of 2020, course directors and faculty worked to make curriculum more effective especially for lessons that 
used small group interactions to reinforce learning objectives. Perhaps the hardest face-to-face teaching method to replicate in an online environment is experiential learning during industrial site visits and field studies. It is impossible to replicate those learning outcomes in a virtual discussion with industry leaders. Not being able to actually see a manufacturing site, a research laboratory, or electric power plant directly impacts learning.

While Islam, Beer, and Slack (2015) delineate technology and technical training as two challenges, both can be examined together. The primary means of online education during the closeout of AY2020 was Blackboard and its collaboration function. Learning to use Blackboard capabilities while simultaneously teaching had a significant impact on both student and faculty effectiveness. The National Defense University upgraded its information systems to add Microsoft Teams capability during July 2020 only weeks before student arrival in August. Given the short transition time between Blackboard and MS Teams, some faculty again had to learn a new technology concurrent with teaching. As the academic year progressed, faculty became more proficient with the technology. With that said, there is a desire by faculty to return to a face-to-face environment, thus some faculty are reluctant to dedicate significant time to training because of opportunity costs. Addressing the future use of online teaching capabilities even during a face-to-face curriculum will need to include dedicated faculty and student training.

Finally, faculty time management experiences at the Eisenhower School are consistent with Islam, Beer, and Slack's (2015) fifth challenge. Asynchronous communication does have advantages (Li, Finley, Pitts, Guo, 2011; Lim, 2017), but it does take longer to communicate with students via email and message boards. Budgeting that additional time often requires faculty to work outside of normal working hours. Faculty also have found it difficult to manage synchronous communications such as real-time chats while simultaneously leading guided discussions, answering student questions, and monitoring student participation. Some faculty have used student leaders to monitor the side chats and interject relevant content verbally to the instructor to better manage classroom time. Further study of Eisenhower School faculty would be necessary to validate the literature's estimates of $30 \%$ increase in time consumption for online versus face-to-face teaching (Islam, Beer, Slack, 2015, p. 108).

\section{Conclusions}

The COVID-19 pandemic put online teaching and learning under a stress-test that definitely accelerated the digitalization of higher education teaching as Manfred Ketx de Vries, one of the prominent professor said: "we achieved something in three months time what we would do in normal conditions in five years time" (www. GBSN Beyond - GBSN, virtual conference, reimagined, 9-13 November 2020) 
The present work was carried out during the initial time of pandemic in Poland and USA when no well-defined guidelines were developed for online education and the focus was to continue the academic process by utilizing all available resources, thus this may be the limitations of the present work in terms of the utilization of resources. Authors noticed that the assessment of line teaching may be different from the perspective of students and academic teachers thus the next step will be to run research amongst academic staff at both Universities. At the same time, the following work provides the future scope for studying and analyzing the shift from face-to-face to online mode with the improved online education as with the passage of time and continuation of online education some standards have been adopted by institutes for improvement in online education.

Nevertheless, it is worth mentioning that online teaching should be regarded as complimentary to traditional teaching, nothing will replace face to face contact. Possibility to see non verbal communication, emotions, making sure that students understand is only viable through personal interactions. Studying is also related to embracing social skills, meeting new people, making friends. This is the only time for students to extend their learning experiences as later in life they will never have enough time to study.

The current study is most important for universities to start the e-learning system in the current COVID-19 situation which is leading to the paradigm shift in the education system. Moreover, this study is helpful because the current situation of COVID-19 required a paradigm shift in the educational industry. Against this background, COVID-19 should additionally be considered as a catalyst for university

systems to better prepare faculty members not only for online teaching, but also for unexpected challenges in general, and to this end, invest further in proactive resilience initiatives (see also Rapanta et al., 2020).

\section{REFERENCES}

[1] Aithal, P.S. and Aithal, S. 2016. Impact of on-line education on higher education system, International Journal of Engineering Research and Modern Education, Vol. 1, No. 1, pp. 225-235.

[2] BALENI, Z. 2015. Online formative assessment in higher education: its pros and cons, The Electronic Journal of e-Learning, Vol. 13, No. 4, pp. 228-236.

[3] Bhat, R., Singh, V.K., Naik, N., Kamath, C.R., Mulimani, P., and KulKarni, N., 2020. COVID-2019 outbreak: The disappointment in Indian teachers, Asian Journal of Psychiatry, 50, 102047, https://doi.org/10.1016/j.ajp.2020.102047.

[4] Chatelier, G. and Voicu, I. 2018. E-learning within the framework of UNESCO, "In the proceedings of the fourteenth international conference on eLearning for knowledge-based society", Thailand.

[5] Chi, M.T., and Wylie, R., 2014. The ICAP framework: Linking cognitive engagement to active learning outcomes, Educational Psychologist, 49(4), 219-243.

[6] Crawford-Ferre, H.G. and Wiest, L.R., 2012. Effective online instruction in higher education, The Quarterly Review of Distance Education, Vol. 13, No. 1, pp. 11-14. 
[7] Demir, M., 2018. Using online peer assessment in an Instructional Technology and material Design course through social media, Higher Education, Vol. 75, pp. 399-414, doi: 10.1007/ s10734-017-0146-9.

[8] Denzin, N., and Lincoln, Y., 2005. Introduction: The discipline and practice of qualitative research. [in:] Norman Denzin \& Yvonna Lincoln (Eds.), The SAGE handbook of qualitative research (pp. 1-32). Thousand Oaks, CA: Sage.

[9] IAU Report (2020), The Impact of Covid-19 on Higher Education Around the World, Published by the International Association of Universities, available at: https://www.iau-aiu.net/IMG/pdf/ iaucovid19_and_he_survey_report_final_may_2020.pdf.

[10] Islam, N., Beer, M. and Slack, F., 2015. E-Learning challenges faced by academics in higher education: a literature review, Journal of Education and Training Studies, Vol. 3 No. 5, pp. 102-112, doi: 10.11114 /jets.v3i5.947.

[11] Khan, S. and KHAN, R.A., 2019. Online assessments: exploring perspectives of university students, Education and Information Technologies, Vol. 24, pp. 661-677.

[12] Li, L., Finley, J., Pitts, J., and Guo, R., 2011. Which is a better choice for student-faculty interaction: synchronous or asynchronous communication?, Journal of Technology Research, Vol. 2, pp. 1-12.

[13] Lim, F.P., 2017. An analysis of synchronous and asynchronous communication tools in e-learning, Advanced Science and Technology Letters, 143(46), 230-234.

[14] Mcconnell, D., 2018. E-learning in Chinese higher education: the view from inside, Higher Education, Vol. 75, pp. 1031-1045, doi: 10.1007/s10734-017-0183-4.

[15] O'Connor, K., 2014. MOOCs institutional policy and change dynamics in higher education, Higher Education, Vol. 68, pp. 623-635, doi: 10.1007/s10734-014-9735-z.

[16] Offir, B., Lev, Y., and Bezalel, R., 2008. Surface and deep learning processes in distance education: Synchronous versus asynchronous systems, Computers \& Education, 51(3), 1172-1183.

[17] O'NeILL, D.K. and SAI, T.H., 2014. Why not? Examining college students' reasons for avoiding an online course, Higher Education, Vol. 68, pp. 1-14, doi: 10.1007/s10734-013-9663-3.

[18] Ortiz, P.A., 2020. Teaching in the time of COVID-19, Biochemistry and Molecular Biology Education, 48(3), 201, https://doi.org/10.1002/bmb.21348.

[19] Ozden, M.Y., Erturk, I. and SAnLI, R. 2004, Students' perceptions of online assessment: a case study, Journal of Distance Education, Vol. 19, No. 2, pp. 77-92.

[20] RaI, L. 2019. Successful learning through massive open online courses, IEEE Potentials, Vol. 38, No. 6, pp. 19-24.

[21] Sarrayrih, M.A. and Ilyas, M., 2013. Challenges of online exam, performances and problems for online university exam, IJCSI International Journal of Computer Science Issues, Vol. 10, No. 11, pp. 439-443.

[22] Shereen, M.A., Khan, S.M., Kazmi, A., Bashir, N. and Siddique, R. 2020, COVID-19 infection: origin, transmission, and characteristics of human coronaviruses, Journal of Advanced Research, Vol. 24, pp. 91-98, doi: 10.1016/j.jare.2020.03.005

[23] Stowell, J.R. and Bennett, D., 2010. Effects of online testing on student exam performance and test anxiety, Journal of Educational Computing Research, Vol. 42, pp. 161-171.

[24] Swan, J.G., 2017. The challenges of online learning, Journal of Learning Design, Vol. 10, No. 1, pp. 20-30, doi: 10.5204/jld.v9i3.293.

[25] Wekerle, C., Daumiller, M., and Kollar, I., 2020. Using digital technology to promote higher education learning: The importance of different learning activities and their relations to learning outcomes, Journal of Research on Technology in Education. Advanced online spublication. https:// doi.org/10.1080/15391523.2020.1799455 


\section{NETOGRAPHY}

[1] Ahmad, I., Jasola, S. and AnUpriYa, 2017. Supplementing higher education with MOOCs: a case $s t u d y$, In the proceedings of International Conference on Emerging Trends in Computing and Communication Technologies (ICETCCT), pp. 1-5, available at: https://ieeexplore.ieee.org/ document/8280346 [date of access: 20.09.2020].

[2] https://www.gov.pl/web/edukacja/zawieszenie-zajec-w-szkolach [date of access: 15.09.2020].

[3] https://MOOC Courses: Massive Open Online Courses [2021 Guide] (mydegreeguide.com) [20.09.2020].

[4] https://www.mooc.org [date of access: 20.09.2020].

[5] https://www.gov.pl [date of access: 15.09.2020]

[6] https://www. GBSN Beyond - GBSN, virtual conference, reimagined, 9-13 November 2020 [date of access, 20.11.2020]. 